\title{
Recycling of flame retardant plastics from WEEE, technical and environmental challenges
}

\author{
Tange, L. ${ }^{a}{ }^{,}$, Van Houwelingen, J.A. ${ }^{b}$, Peeters, J.R. ${ }^{c}$, Vanegas, P. ${ }^{c}$ \\ ${ }^{a}$ ICL-IP Europe and EFRA,Frankrijkweg 6, 4538 BJ, Terneuzen, Netherlands \\ ${ }^{b}$ Recycling Consult BV, Coördinator REWARD Eindhovenseweg 29A, 5633 BD, Eindhoven, Netherlands \\ ${ }^{c} \mathrm{KU}$ Leuven, Department of Mechanical Engineering, Center for Industrial Management, 3001 Heverlee, Belgium
}

\section{A B S T R A C T}

The European Flame Retardant Association (EFRA) combines leading companies offering the largest spectrum of flame retardants (FRs). EFRA conducted many studies on the recycling of FRplastics. This study concerns the recycling of plastics from liquid crystal displays (LCDs) and addresses the RoHS and WEEE directives (Restriction on Hazardous Substances and Waste Electrical and Electronic Equipment), requiring a higher tonnage of recycled plastics. Recycling standards are developed within the committee IEC TC111. A new technical report IEC/TR 62635 Ed1.0: "Guidelines for End-of-Life information provision from manufacturers and recyclers, and for recyclability rate calculation of Electrical and Electronic Equipment", aims for better and higher quality of recycled materials. EFRA cooperated with REWARD, a project in the ECOINNOVATION program of FP7, with partners Recycling Consult, Coolrec/PHB and BRGM. Due to higher external fire safety requirements for TV housings in Europe, more FR-plastics need to be recycled following the recast of the WEEE directive. As a consequence WEEE plastics need to be processed by mechanical recycling instead of energy recovery. The EFRA and REWARD study describe composition, characterization, identification, size reduction and separation techniques. This article provides guidance to achieve the required plastic qualities and its limitations due to separation constraints and miscibility problems of the different plastics. A separation route on paper is developed for plastics from back covers of LCDs. It is found that a combination of mild size reduction, density separation and sensor based sorting gives the best results. Fractions are tested for their miscibility with virgin plastics by producers. The findings are of importance since presently solutions for FR-plastic separation are hardly offered.

(C) 2013 PEI, University of Maribor. All rights reserved.
\end{abstract}

\section{ARTICLE INFO}

Keywords:

Flame retardant plastics

Size reduction

Separation

WEEE

Sensor based sorting

*Corresponding author:

Tange@icl-ip.eu

(Tange, L.)

\section{References}

[1] Imai, T., Hamm, S., Rothenbacher, K.P. (2003). Comparison of the recyclability of flame retarded plastics, Environmental Science \& Technology, Vol. 37, No. 3, 652-657.

[2] Eldik, R. (1999). Report by University of Erlangen, Institute for Inorganic Chemistry, University of Erlangen.

[3] The European parliament and the council of the EU, Directive 2011/65/EU, from http://eurlex.europa.eu, accessed June 10, 2012.

[4] European Flame Retardants Association, from http://www.flameretardants.eu, accessed June 1, 2012.

[5] REWARD. Recovery of electronic waste through advanced recycling and demonstration, A three year project in the Eco-Innovation Program of EACI, Brussels, from http://www.reward-weee.eu, accessed June 1, 2012.

[6] European commission, from http://ec.europa.eu/atoz_en.htm, accessed June 10, 2012.

[7] Salhofer, S., Spitzbart, M., Maurer, K. (2011). Recycling of LCD screens in Europe - State of the art and challenges, In: Proceedings of $18^{\text {th }}$ CIRP International Conference on Life Cycle Engineering - Globalized Solutions for Sustainability in Manufacturing, Technische Universität Braunschweig, Braunschweig, 454-458. 
[8] Zachmann, G. (1997). Rapid characterization of black plastics by MID infrared reflectance spectroscopy, In: Barrage, A., Edelmann, X. (eds.), R’97 Recovery Recycling Reintegration, Vol III, Mechanical Processes Separation Technologies, Logistic Networks.

[9] Menad, N., Guignot, S., Van Houwelingen, J.A. (2012). New Characterization method of electrical and electronic equipment wastes (WEEE), Waste Management, Vol. 33, No. 3, 706-713.

[10] Peeters, J.R., Vanegas, P., Devoldere, T., Dewulf, W., Duflou, J.R. (2013). Product clustering for closed loop recycling of flame retardant plastics: A case study for flat screen TVs, In: Proceeding of $20^{\text {th }}$ CIRP International Conference on Life Cycle Engineering, Singapore.

[11] EACI (2007-2013). Bringing dark plastics to light, Boosting green business, from http://ec.europa.eu/environment/eco-innovation/files/docs/publi/eaci_brochure_eco_innovation_a4_lr_en.pdf, 16, accessed July 1, 2013.

[12] Morrish, L., Morton, R., Myles, N. (2009). Flat panel display recycling technologies, TITECH FPD Sorting Trial, WRAP MDD014 - Trial Report, July 2009, Axion Consulting, from http://www.wrap.org.uk, accessed June 10, 2012.

[13] Kobler, R., Foss, H. (2004). Successful recovery of end of life electronics plastics using RPIs skin flotation technology, GPEC 2004 Paper Abstract \#32.

[14] Vanegas, P., Peeters, J.R., Devoldere, T., Cattrysse, D., Duflou, J.R. (2012). Closed loop recycling of Philips TV housing plastics, In: Proceedings of i-SUP 2012 International Conference - Innovation for Sustainable Production, Bruges, Belgium. 